\title{
58. SLIM HOLES DRILLED ON THE ALGERIAN SHELF
}

\author{
P. F. Burollet, A. Said, and Ph. Trouve, Compagnie Français des Petroles, Paris, Cedex 15, France
}

\section{INTRODUCTION}

Research and exploration offshore Western Algeria began as long ago as 1968 . Several seismic campaigns, a gravimetric campaign and an aeromagnetic campaign, were undertaken. these surveys allowed us to prepare a new bathymetric map which showed us that the old map was inaccurate.

The quality of seismic data was not always good. The first campaign to systematically collect geophysical data was begun by the Algerians in 1968 along the Algerian coast. It was limited to regions where water depth does not surpass 200 meters. A $3500-\mathrm{km}$ line was shot in a zone extending $18 \mathrm{~km}$ from the Algerian coast. Another $2700 \mathrm{~km}$ were shot in $1969 / 1970$ and finally, in 1973/1974 a deep-water campaign was undertaken and an additional $10,000 \mathrm{~km}$ were shot. These different surveys were executed by three companies using different methods.

The first survey, conducted by Teledyne, utilized analog equipment with the potential of digitization before processing. A 120,000 Joules sparker was used for the energy source. The recording is in 24 -fold coverage.

Data from the second survey, conducted by Globe Universal Sciences Inc., were recorded entirely in digital and 24-fold coverage. "Bolt Par Air Guns," each with 300 cubic/inch (4.916 liters) chambers, were used for the energy source during this survey. Two to four guns fired simultaneously at 1379 dynes/sq. cm of air pressure provided sufficient energy down to 6.0 seconds of seismic time. A hydrophone array, a 24station Mandrel streamer cable with 60 hydrophones per station, was used throughout the survey. Each station consisted of a 61-meter "live" cable section of hydrophones and a 39-meter "dead" or spacer cable section. The seismic data were recorded digitally using the Globe-leach 4000 (HDDR).

Data from the third survey, conducted by S. S. L. in 24-fold coverage, were also completely digital. Gas guns were used as the energy source ( 8 guns). The time interval between shots points was 15 to $23 \mathrm{sec}-$ onds, equivalent to 50 meters: 20 shot points/kilometer. The seismic data were recorded with a DFS III and a 48-channel cable, 2680 meters long with 48 groups of hydrophones of 32 hydrophones each.

The results were of much higher quality than previous surveys and four reflectors were distinguished:

M: top of the Miocene evaporites.

$\mathrm{K}$ : top near the top of saliferous formation; this reflection cannot be distinguished everywhere.

$\mathrm{L}$ and $\mathrm{O}$ : pre-evaporite beds. It is difficult to follow these horizons everywhere.

In order to corroborate and tie in our seismic studies, two slim holes were drilled; Algiers 1 and
Arzew 1. Algiers 1 was drilled in 100 meters of water to a depth of 1205 meters. Arzew 1 was drilled in 127 meters of water to a depth of 1034 meters.

\section{BACKGROUND}

The Algerian continental margin is a narrow area of sharp transition between the very flat sea floor of the deep Algera-Provencal Basin and the Atlas Mountains.

The shelf is very narrow $(4-20 \mathrm{~km})$ except for a few embayments. The shelf widens both to the west and the east in Morroco (Alboran Sea) and in Tunisia. The slope is very steep and deeply dissected by numerous canyons. The continental rise is restricted and the 2600 -meter isobath markedly delineates the exceedingly flat deep-sea basin. The hypsometric histograms of the whole Mediterranean show a bimodal distribution of water depths with a main class corresponding to the interval $0-500$ meters (35\% of the area) and the secondary mode in the 2000-3000 interval (nearly $40 \%$ by addition of 2000-2500 and 2500-3000). The same calculation for the Algerian offshore shows $80 \%$ of the area falls in the 2000-3000 meter range, and less than $10 \%$ of the area is continental shelf.

During Tertiary time several tectonic phases disturbed the Atlas Mountains. The main one, from the Eocene to early Miocene, resulted in the formation of southward thrusting nappes. These nappes are formed by compressional movements augmented by gravitational movements, especially during the lower Miocene.

These tectonic events were followed by erosion, local subsidence, and deposition of thick post-orogenic series. The latter events, sometimes of molassic type, are localized in numerous basins, for example, the well-known Mitidja and Cheliff basins, and are separated from each other by local depressions or emergent highs.

The Miocene post-orogenic deposits are mainly composed of marine clays with sandstone and limestone intervals. Some intercalations of volcanic material occur at various levels. In the Cheliff interior basin the post-orogenic Miocene series contains dolomites and cherts and is capped with a Messinian gypsum member. In general, the post-nappe Miocene transgressive series extends from the Langhian to the Messinian.

A new orogenic phase occurred at the end of the Miocene which produced vertical movements, giving rise to anticlines, faults, and gravitational movements on the flanks of the uplifted substrata giving rise to locally overturned beds. So the marine transgressive Pliocene sediments, deposited in basins present during late Miocene time, lies unconformably over the Miocene. The lower Pliocene is generally composed of marls with a pelagic fauna, which in some cases pass laterally to sands or algal limestones towards the edge of the basin. The middle and upper Pliocene is com- 
posed of neritic sandstones overlain by calcareous sands and lacustrine limestones, the upper part of which corresponds to the Villafranchian.

At the end of the Villafranchian another tectonic phase with vertical movements occurred which gives us the present-day form of the Atlas Mountains, and folded the Miocene-Pliocene series often into bedsasymmetrically overturned toward the north. The folding was probably produced by gravity sliding in response to the void created by the downfaulting of the Mediterranean. Recent sediments on the shelf are mostly sand and silt. Sand is found well beyond the present wave base, in water depths as great as 200 meters, which means that it is mostly a relict deposit, having been deposited in shallow waters.

Seismic records of the shelf show major unconformity surfaces. One of them corresponds to the top of the pre-Miocene basement. Sometimes slumping of Tertiary to Recent sediments occurs along this unconformity in deeper water.

The Algerian slope has been downwarped as a result of the late Miocene and Pliocene tectonic phases. In the deep-sea basin, below the Pliocene deposits, evaporites and massive salt layers are present as described by many authors who consider them to be of Messinian age. The base of the salt, which can be followed throughout the Algero-Provencal Basin, corresponds to the top of the Miocene sedimentary sequence of the deep-sea area.

\section{WELL ALGER-1}

Latitude: $36^{\circ} 46.30^{\prime} \mathrm{N}$

Longitude: $2^{\circ} 44.21^{\prime} \mathrm{E}$

Water depth: 100 meters

The well was spudded on 25 May 1974 and was plugged and abandoned on 6 June 1974. It was drilled to a depth of 1193 meters below sea level. The well was located on a Miocene-Pliocene anticline defined from the seismic profiler records. Cuttings were taken from below 137 meters (Figures 1 and 2). From top to bottom (all depths below sea level) they are:

137 to 165 meters: Sand and sandstone with marl intercalations. This sequence contains very few foraminifera. Only badly preserved Globorotalia and a few reworked Cretaceous forms are present. The environment could have been shallow marine with coastal or lacustrine influence.

165 to 341 meters: Gray plastic marls, slightly gypsiferous with pyrite and rare quartz crystals. This sequence is very rich in planktonic foraminifera and is lower Messinian (Globorotalia plesiotumida Zone). The benthic foraminifera are rare, especially near the top. The sequence could have been deposited in an outer shelf environment as evidenced by a high percentage of pelagic foraminifera $(80 \%-95 \%$ '

341 to 635 meters; Gray plasuc marls, slightly gypsiferous, locally pyritic with fine sandstone intercalations. Glauconite is present. This sequence is more indurated than the overlying one. The microfauna is rich and permits the following subdivisions:

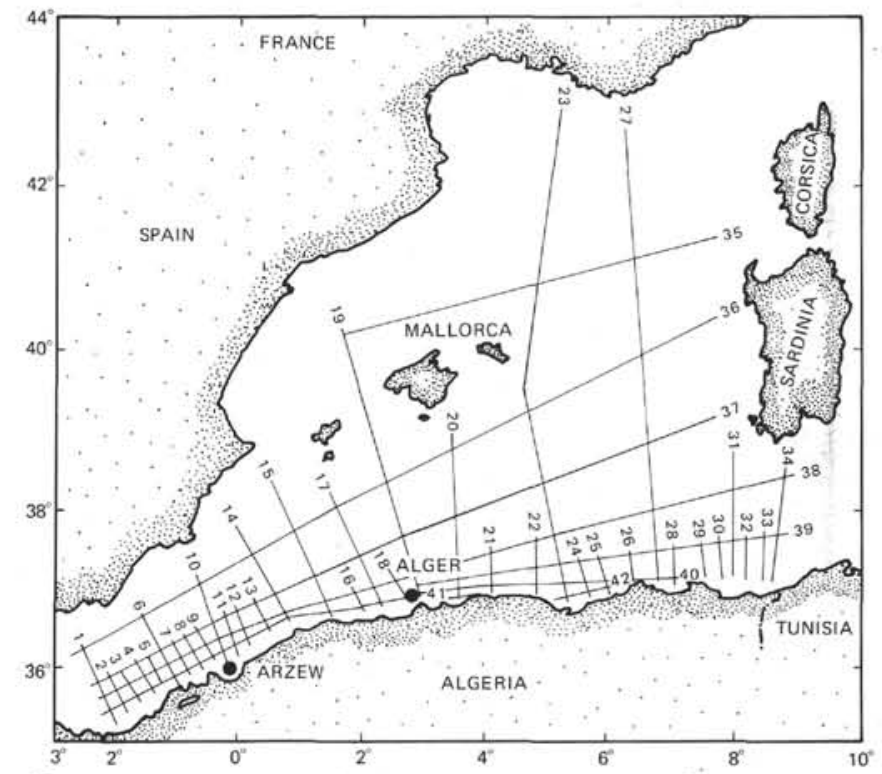

Figure 1. Location of Alger-1 and Arzew-1 wells.

From 360 to 513 meters; Globorotalia merotumida/ Globorotalia acostaensis Zone.

From 513 to 635 meters: Globorotalia acostaensis/ Globorotalia menardii Zone.

Both zones are of Tortonian age. They were also probably deposited in an outer shelf environment and have a high percentage of pelagic foraminifera (60\%$95 \%)$.

635 to 1062 meters: Gray plastic marls with fine limestone intercalations from 776 meters. The marls become more calcareous with the occurrence of pyrite and glauconite, and progressive reduction in the kaolinite content with depth. The planktonic foraminifera are abundant throughout this interval and belong to the Globorotalia mayeri Zone, which enables us to date this series as Serravallian. Benthic foraminifera are abundant and the fauna is very diversified, and contains more arenaceous types than in the overlying upper Miocene sediments. The percentage of pelagic foraminifera is still high ( $\geq 80 \%$ ) with the exception of between $690-750$ meters in which it is only $60 \%$. The Serravalian/Tortonian contact has been fixed at 635 meters in view of the distribution of Globorotalia siakensis, and does not correspond to a lithological break. The lithology changes gradually from one series to the other. The main change in lithology occurs between 776 meters and 853 meters, and is accompanied by an increase of dip with depth.

1062 to 1183 meters: Marls with more calcareous intercalations than in overlying beds and containing calcite, phosphates, and glauconite. The marls are richer with fine limestone intercalations (foraminiferous biomicrites); planktonic and benthic foraminifera are abundant and the fauna is diversified. There is no distinctive species of Globorotalia and, for this reason this sequence could either belong to the Globorotalia mayeri Zone or to the Orbulina Zone of upper Langhian to Serravallian. 


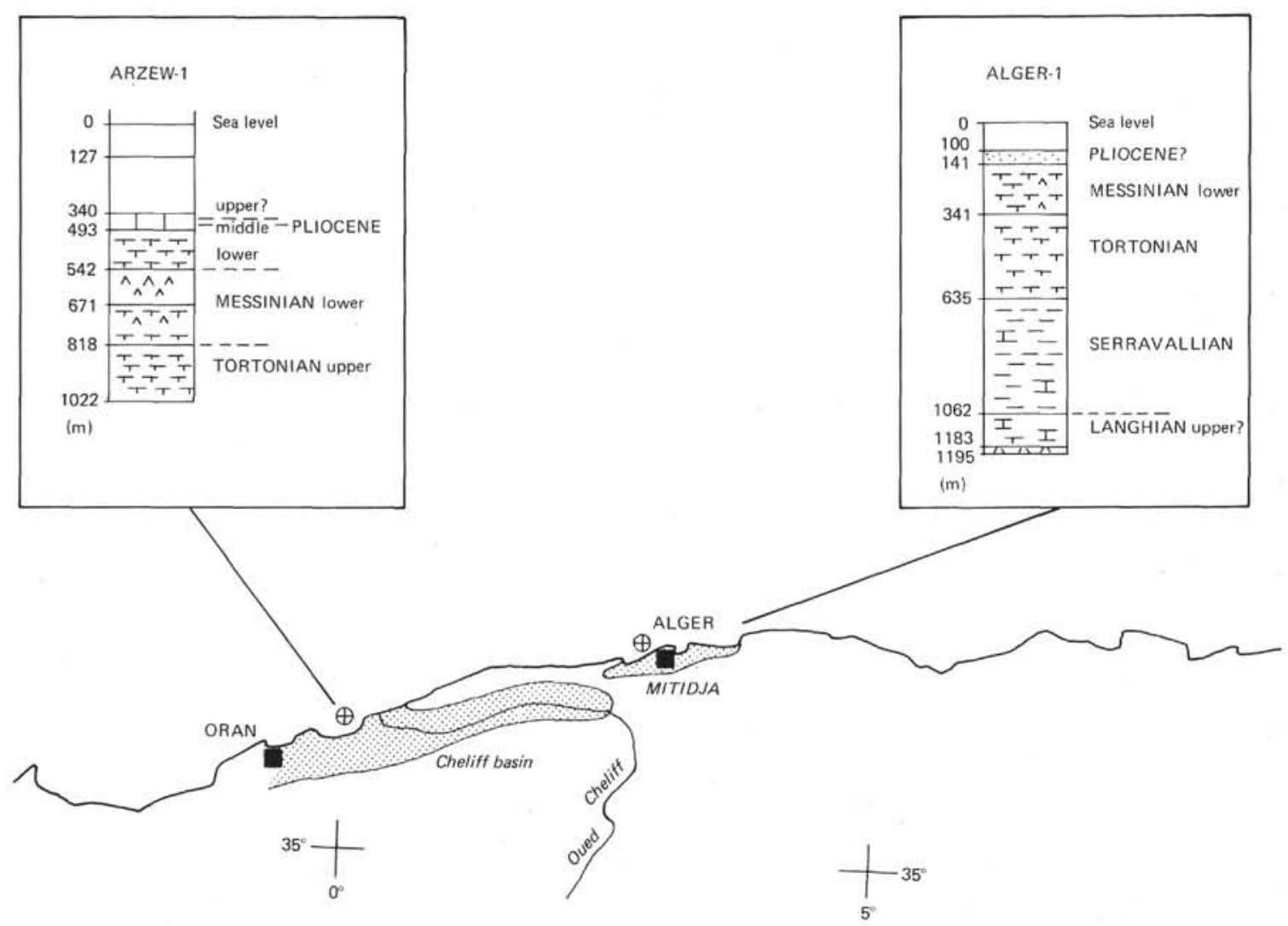

Figure 2. Location and stratigraphic sequence of slim holes on the Algerian shelf.

1183 to 1195 meters: Volcanic sedimentary formation composed of tuffaceous zones in which trachyandesitic elements occur in the decayed and diagenetically altered argillaceous or glassy matrix. Detrital quartz is present.

The lithological composition suggests that this was most probably a lava which was subsequently weathered and eroded and from which freed elements were redeposited together with other terrigeneous material. Because of the presence, between 1178-1183 meters, of tuffs mixed with calcimicrites, identical to those found higher in the sequence (1130-1170 m), we can assign an identical age (upper Langhian to Serravallian) to this series $(1062-1195 \mathrm{~m})$.

\section{WELL ARZEW-1}

Latitude: $36^{\circ} 02^{\prime} 45.7^{\prime \prime} \mathrm{W}$

Longitude: $00^{\circ} 02^{\prime} 55.5^{\prime \prime} \mathrm{W}$

Water depth: 127 meters

The well was spudded on 28 November 1975 and plugged and abandoned on 5 December 1975 at a depth of 1022 meters sub-sea level. It was drilled on a seismically defined Miocene-Pliocene nose (Figures 1 and 2). Cuttings were taken from below 340 meters. From top to bottom (all depths below sea level) they are:

340 to 493 meters: Lithothamnium and fossiliferous limestones with gray silty marl intercalations. Pyrite and glauconite is present between 358-452 meters.

493 to 542 meters: Gray compact pyritic marls with reworked gypsum at base (derived from the underlying sequence). Planktonic foraminifera are abundant and permit the following subdivisions:

From 340 to 349 meters: Globorotalia inflata

Zone: upper Pliocene.

From 359 to 452 meters: Globorotalia crassaformis

Zone: middle Pliocene.

From 452 to 542 meters: Globorotalia margaritae

Zone: lower Pliocene.

The environment during deposition of the upper and middle Pliocene could have been middle to outer shelf, and deeper shelf for the deposition of the lower Pliocene.

542 to 671 meters: Massive gypsum with rare marl intercalations. One of these intercalations (at $574 \mathrm{~m}$ ) enables us to assign a Messinian, probably lower Messinian age to the sequence on the basis of its similarity to the laminated levels of the Spanish "Levante."

671 to 818 meters: Gray marls and clays with some gypsum intercalations. Volcanic elements are rare from 768 to 815 meters. Pyroclastic material of rhyolitic (ignimbritic) origin, deposited in a marine environment, occurs between 815 and 818 meters. The microfauna is locally abundant and indicates the sequence is Messinian in age Globorotalia plesiotumida/Globorotalia conomiozea Zone).

818 to 1022 meters: Gray marls with fine intercalations of pyroclastic material. The microfauna indicates that the series is Tortonian (Globorotalia merotumida/ Globorotalia cultrata Zone). The depositional environment could have been an outer to middle shelf. 